UDC 66.099.2; 552.52

\title{
DROP METHOD OF OBTAINING GRANULES OF THE SAME DIAMETER FROM FINE CLAY IN A DISK GRANULATOR
}

\author{
I.A.Talibly, G.M.Samedzade, Sadikhov F.M., A.M.Gasimova, V.A.Gasimov, \\ G.B.Shadlinskaya
}

\author{
M.Nagiyev Institute of Catalysis and Inorganic Chemistry, NAS of Azerbaijan \\ Azerbaijan State Pedagogical University
}

sakasim45@mail.ru

Received 17.09.2019

Accepted 24.01.2020

\begin{abstract}
The obtaining of granules with given sizes from clay powder in a two-section disk granulator with coaxial sides under the impact of drops of a binding liquid of the same diameter was studied. Optimum granulation time was determined in the first section with excessive powder and in the second section without powder contributing obtaining of round granules with sphericity of not more than 0.850 and similar granulometric composition. It was established that the value of formed granules is determined with the size of fed drops of binding liquid, strength increases with the rise of their diameter. However, as the diameter increases density limit decreases. It was shown that initial stages of granulation process have the greatest impact on potential mechanical strength of granules. Dependence of drop size of a solution to obtain granules of a given diameter was determined.
\end{abstract}

Keywords: two-section granulator, powdery clay, drops a binding liquid, tensile strength, granulation time.

doi

\section{Introduction}

One of the main problems of preparing ball-shaped catalysts from clays is their stickiness and in this connection obtaining of granules with similar diameter. This problem has always been under attention of researchers. Due to fibrinous property of clays the pulping machines from where the material is pressed out in the form of wet lamps which are cut off and granulated with powder in cylinder or disk granulators, were created [1]. The method of obtaining spherical molecular sieve by granulation in disk granulator by injecting the solution of sodium aluminate was developed [2]. There has been proposed the method of granulating powder which moves on horizontal band on which the drops of binding solution fall, and then formed lamps are granulated in cylinder granulator [3]. There is also vibro-granulator in which drops are injected into vibrating layer of powder from drop sensor located on the bottom of vibrating chamber [4]. There is also a number of granulators $[5,6]$ in which authors tend to obtain ball-shaped granules with given size and properties.

However, for practical purposes, particularly during developing carrier of catalyst from clays homogeneity of the diameter of catalyst is important. That is why the aim of the work is to obtain granules with given size and properties, to select drops for obtaining necessary diameter of a granule.

\section{Research method}

We have studied the impact of the main parameters of the process (rotation rate of a disk, dependence of diameter of granule on the value of supplied water drop, pelletizing time and so on) on fractional composition, form and strength of granules. Studies were performed on twosection disk granulator described in Figure 1.

Granulator consists of disk-1, representing tin disk wheel. Diameter of a disk on external bead with height of $25 \mathrm{~mm}$ is $270 \mathrm{~mm}$, but diameter on inner bead with height of $12 \mathrm{~mm}$ of the first section is $180 \mathrm{~mm}$. On the back side of a disk the flange 3 was fastened in its center with the help of which the disk was attached to 
the reduction axle 4 . Reducing gear was connected to motor 5 by six rods with the help of which the number of disk rotations changes. The system motor-reducing gear - disk was installed in the frame 6 by lifting the ends of which we may change its inclination angle towards horizon. Bin 8 for finished granules was installed under the disk. Bin 2 with outlet for supplying granule powder was installed abone the disk.

Along outlet of the bin 2 fine clay was directed to the first section of the disk to the right, drops with given size were supplied from capil- lary 10 to the middle of dropping clay to the left from the center (disk rotates clockwise). After pelletizing obtained granules with powder were rolled to the second section and pelletized within a given time without powder. Strength of granules was determined after drying on the table and at $110^{\circ} \mathrm{C}$ on device Fika. The clay with the following composition was granulated (\% mass): quartz - 45.0, muscovite 2M1 - 29.5, dickite $2 \mathrm{M} 1$ - 6.4, octadecacyl - 1.5, muscovite 2M2-17.6 defined on X-ray diffractometer "D2 Phaser" of the "BRUKER" company. The data of X-ray pattern are given in Figure 2.

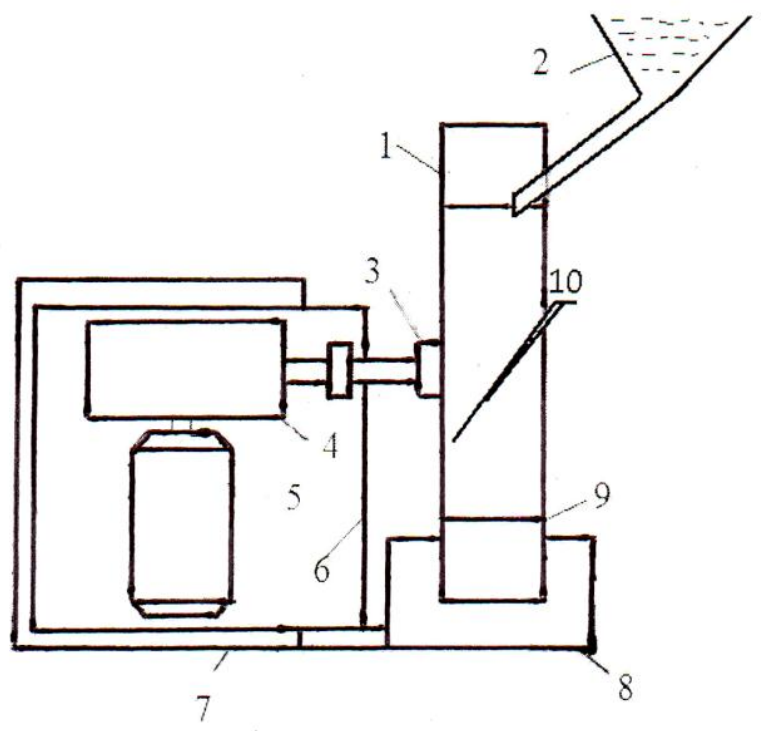

Fig. 1. Scheme of laboratorial disk granulator: 1 - disk wheel of bottom with bead and ring for inner section, 2 - feeding bin with powder, 3 flange, 4 - reducing gear, 5 - electric motor, $6-$ frame, 7 - base, 8 - bin for end product, 9 - ring of inner section of granulator, 10 - capillary.

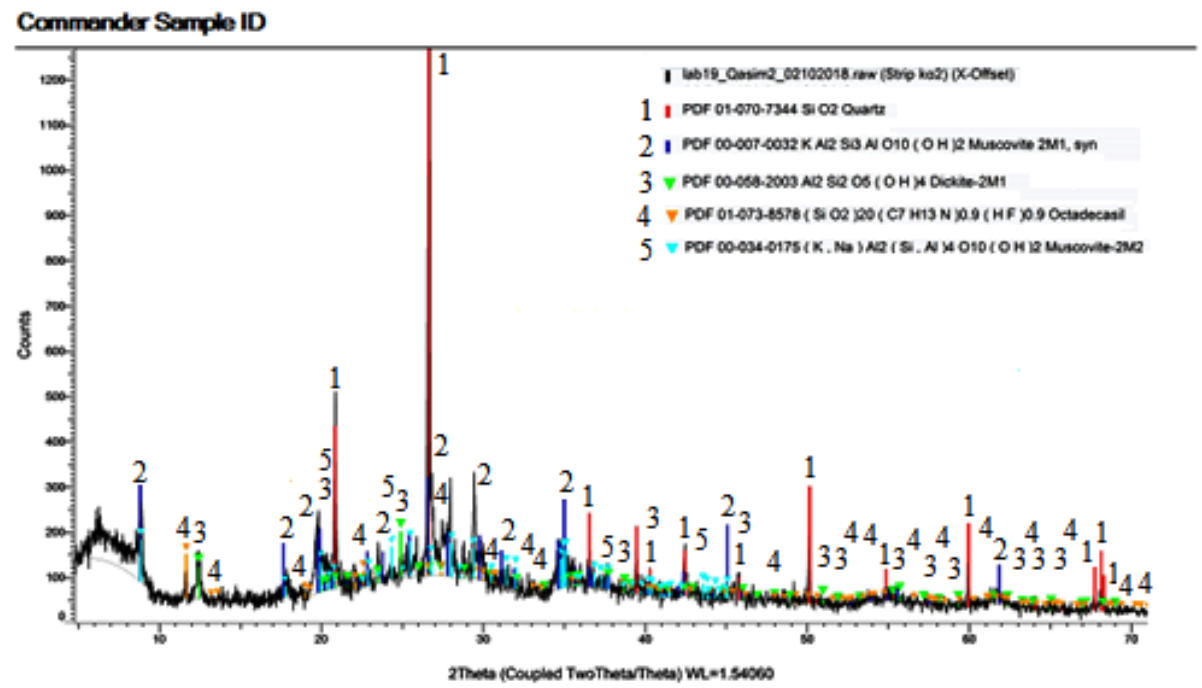

Fig. 2. X-ray pattern of granulated clay: 1 - quartz, 2 - muscovite $2 \mathrm{MI}, 3$ - dickite $2 \mathrm{M} 1$, 4 - octadecacyl, 5 - muscovite 2M2. 
Table 1 shows the data on granulation of clay using the drops with different diameters. Granules were granulated in the first section in powder layer for a minute, and then granules were rolled to the second section and pelletized without powder. As is seen from Table during pelletizing in powder layer diameter of a granule somewhat increases - from 3.82 to 4.12 $\mathrm{mm}$ (for $7.82 \%$ ), but during pelletizing for 15 min. without powder in the second section slightly decreases from 4.12 to $3.81 \mathrm{~mm}$ (for $7.28 \%$ ). At pelletizing without powder the surface of granules is moistened from excess moisture inside letter ones protruding to the surface due to capillary and centrifugal forces.

Table 1. Dependence of diameter of granules on diameter of drops and time of their pelletizing

\begin{tabular}{|c|c|c|c|c|c|}
\hline \multicolumn{2}{|c|}{$\begin{array}{c}\text { Pelletizing } \\
\text { time }\end{array}$} & $\begin{array}{c}\mathrm{k}-19 \\
\text { drop/ml } \\
F_{\text {drop }}= \\
4.65\end{array}$ & $\begin{array}{c}\mathrm{k}-45 \\
\text { drop/ml } \\
F_{\text {drop }}= \\
3.89\end{array}$ & $\begin{array}{c}\mathrm{k}-82 \\
\text { drop/ml } \\
F_{\text {drop }}= \\
2.856\end{array}$ & $\begin{array}{c}\mathrm{k}-95 \\
\text { drop/ml } \\
F_{\text {drop }}= \\
2.72\end{array}$ \\
\hline \multirow{2}{*}{$\mathrm{s}$} & min & $\begin{array}{c}F_{\text {gran }}, \\
\mathrm{mm}\end{array}$ & $\begin{array}{c}F_{\text {gran }}, \\
\mathrm{mm}\end{array}$ & $\begin{array}{c}F_{\text {gran }} \\
\mathrm{mm}\end{array}$ & $F_{\text {gran }}, \mathrm{mm}$ \\
\hline 10 & 0.1667 & - & - & - & 3.82 \\
\hline 20 & 0.3333 & - & - & - & 4,0 \\
\hline 40 & 0.6667 & - & - & - & 4.08 \\
\hline 60 & 1 & 6.81 & 5.18 & 4.26 & 4.12 \\
\hline & 5 & 6.39 & 4.89 & 4.26 & 3.94 \\
\hline & 10 & 6.06 & 4.73 & 4.0 & 3.9 \\
\hline & 15 & 5.95 & 4.61 & - & 3.81 \\
\hline
\end{tabular}

Proceeding from the data presented in Table 1 , the dependence granules diameter curve on diameter of drops was constructed in rectangular coordinate system. Herewith, on the abscissa axis diameter of drops were laid off in a scale, but on the ordinate axis - diameter of granules and through obtained points we constructed a straight line the inclination angle (Figure 3 ) of which to abscissa axis equals to $\alpha$, and $\operatorname{tg} \alpha=F_{\text {drop }} / F_{\text {gran }}$.

From here

$$
F_{\text {drop }}=F_{\text {gran }} \cdot \operatorname{tg} \alpha,
$$

where $F_{\text {drop }}$ - drop diameter, $F_{\text {gran }}$ - granule diameter. Based on the formula (1) for producing a granule with given diameter at granulation it is important to use drops of a certain diameter.

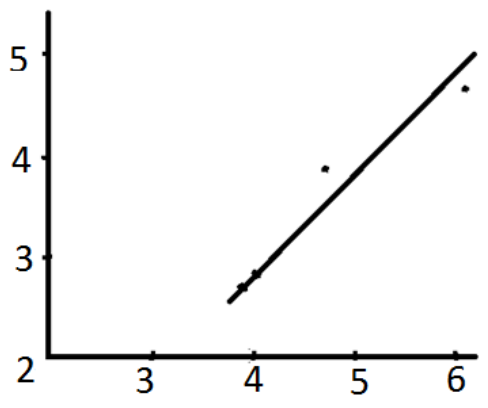

Fig.3. Dependence of diameter of granules on diameter of a drop.

Since $\operatorname{tg} \alpha$ is determined by the ratio of $F_{\text {drop. }} / F_{\text {gran. }}$, then based on tabular data we will determine the average of this value using it for $F_{\text {gran }}$ the data for granules under pelletizing is $10 \mathrm{~min}$. We find $4.65 / 6.06=0.77,3.89 / 4.73$ $=0.82,2.86 / 4=0.71$ and $2.72 / 3.86=0.71$; then average value of $\operatorname{tg} \alpha=0.75$. If we take necessary diameter of granules equal to 2, 3, 4, 5 and $6 \mathrm{~mm}$, then the drops with diameters of 1.5 , $2.25,3.0,3.75$ and 4.65 will be needed to obtain them.

Diameter of drops supplied to granulation was determined according to their amount in $1 \mathrm{ml}$ of water. Since $4 / 3 \pi r^{3} \cdot k=1000 \mathrm{~mm}^{3}$, then

$$
r=\sqrt[3]{\frac{3 \cdot 1000}{4 \pi k}}
$$

on this case diameter of drop $F_{\text {drop }}=2 r$ and

$$
F_{\text {drop }}=12.4091 \sqrt[3]{1 / k}
$$

where $F_{\text {drop }}$ - diameter of drop, mm; $k$ - amount of drop in $1 \mathrm{ml}$.

Table 1 shows that for granules with diameter of 4 and $6 \mathrm{~mm}$ it necessary to apply drops of 2.86 and 4.65 diameters, at $k=82$ and 19 , correspondingly. Based on the formula (1) we find that for granules with diameters of 2,3 , and $5 \mathrm{~mm}$ it is necessary to use drops with diameters of $1.5,2.25$ and $3.75 \mathrm{~mm}$, at $k=627$, 180 and $35 \mathrm{~mm}$, correspondingly. The results were presented in Table 2 . 
Table 2. Average diameter of drops necessary for obtaining granules with given diameter determined from figure 3 and formulas (1) and (2)

\begin{tabular}{|c|c|c|c|c|c|}
\hline $\begin{array}{c}\text { Necessary diameters } \\
\text { of granules, } \\
\mathrm{mm}\end{array}$ & $\begin{array}{c}\text { Data from } \\
\text { the figure 3 } \\
\operatorname{tg} \alpha=0.75\end{array}$ & $\begin{array}{c}\text { Data of from } \\
\text { formula (1), } \\
\operatorname{tg} \alpha\end{array}$ & $\begin{array}{c}\text { Data of } \\
\text { formula (2) } \\
k\end{array}$ & $\begin{array}{c}\text { Average data of } \\
\text { drops, diameter } \\
\mathrm{mm}\end{array}$ & $\begin{array}{c}\text { Diameters of granules } \\
\text { obtained practically, } \\
\mathrm{mm}\end{array}$ \\
\hline 2 & 1.5 & - & 627 & 1.45 & 2.5 \\
\hline 3 & 2.25 & 0.7 & 180 & 2.2 & 3.1 \\
\hline 4 & 3.0 & 0.71 & 82 & 2.86 & 4.02 \\
\hline 5 & 3.75 & 0.82 & 34.8 & 3.8 & 5.37 \\
\hline 6 & 4.5 & 0.767 & 19 & 4.65 & 6.16 \\
\hline
\end{tabular}

\section{Study of the strength of granules}

To find an optimum mode for pelletizing granules we have studied the impact of pelletizing time for 3, 5, 10 and 15 minutes on the form and strength of obtained drop-granules. The results were given in the Table 3 .

As it is seen, the main strength of dropgranule at pelletizing is formed in the first 2-3 min. after its formation. The best results on the form of drop-granule and their strength were obtained during pelletizing in the first section with powder for a one min, and then in the section without powder for 5-10 min.

As Table data show with the growth of sizes of granules the strength of granules increases, however the value of ultimate strength decreases.

\section{Results and discussion and conclusion}

At pelletizing in the first section with powder the surface of granules has the shape of balls spilled with powder. During pelletizing for a one minute the humidity of granules makes up $18-22 \%$. During pelletizing of such granule in the second section without powder excess moisture covers its surface and the granule hardens and becomes smooth, but moisture evaporates and makes up 14-16\%.

Under granulation in powder for one minute and further granulation without powder the surface of granules does not waterlogged, and consequently, costs for its drying and further annealing reduce.

The investigations determined that during pelletizing in the first section with excessive powder for one minute and in the second section without powder for 10 minutes granules with sphericity of not less than 0.85 and identical granulometric are obtained. As the data from Table 3 shows the main strength of granules is formed in the first three minutes and further pelletizing increases the strength only for 40-60 g. That's why for an optimum time of pelletizing we take one minute in the first section with powder and 10 minutes in the second section without powder that causes smooth and durable granules surface.

As Table 3 shows crushing strength of granules increases with the growth of granule size, however tensile strength decreases from 0.23 to $0.11 \mathrm{MPa}$ for granules with diameter of 3.5 and 5.5, correspondingly.

Table 3. Impact of pelletizing time on ultimate strength and strength of granules in their different diameters

\begin{tabular}{|c|c|c|c|c|c|c|}
\hline \multirow{4}{*}{$\begin{array}{c}\text { Granulation } \\
\text { time, } \\
\text { min }\end{array}$} & \multicolumn{6}{|c|}{ Diameter of granules, $\mathrm{mm}$} \\
\hline & \multicolumn{2}{|c|}{$3-3.35$} & \multicolumn{2}{|c|}{$4-4.5$} & \multicolumn{2}{|c|}{$5-5.5$} \\
\hline & \multicolumn{6}{|c|}{ Strength of granules } \\
\hline & $N /$ granule & $\mathrm{MPa}, N / \mathrm{mm}^{2}$ & $N /$ granule & $\mathrm{MPa}, N / \mathrm{mm}^{2}$ & $\mathrm{~N} /$ granule & $\mathrm{MPa}, N / \mathrm{mm}^{2}$ \\
\hline 3 & 7.4 & 0.223 & 8.09 & 0.143 & 9.163 & 0.106 \\
\hline 5 & 7.5 & 0.226 & 8.53 & 0.150 & 8.991 & 0.104 \\
\hline 10 & 7.69 & 0.232 & 8.87 & 0.156 & 9.653 & 0.112 \\
\hline 15 & 7.84 & 0.236 & 9.02 & 0.159 & 9.996 & 0.105 \\
\hline
\end{tabular}




\section{References}

1. Fetisliamov Z.A., Stolbovoi G.V., Arav R.I., Pereverzev A.P. Ustroistvo dlia formovaniia granul iz glinistogo materiala. A.s. 837391 SSSR. B.I. 1981. № 22.

2. Kanavetc P.I., Misin M.S., Sporius A.E., Handros L.B., Chernykh V.I., Melentev P.N., Kulikov G.A. Sposob polucheniia molekuliarnykh sit sfericheskoi formy putem granulirovaniia. A.s. 169088 SSSR. B.I. 1965. № 6.

3. Pat. 527129 SSSR. Sposob granulirovaniia poroshkov. Hugo Villem, Houts Muller. 1976.
4. Efremov V.V., Mozolin N.A., Vitiugin V.M., Vitiugin A.V. Vibratcionnyi granuliator dlia poroshkoobraznykh materialov. A.s. 929192 SSSR. B.I. 1982. № 12.

5. Pat. 3311680 USA. Process and apparatus for pelletizing ponderous materials by vibrational forces/shinobu/ Makino. 1967.

6. Kelbaliev G.I., Sadyhov F.M., Samedzade G.M., Mamedov A.N., Tagiev D.B. Teoriia i praktika granulirovaniia poroshkoobraznykh materialov. Baku: Leman, 2016. $328 \mathrm{~s}$

\section{BOŞQABVARI DəNOVӘRLəŞDİRICIIDə TOZVARI GILDӘN EYNI DİAMETRə MALİK DONOVORLORIN DAMCI ÜSULU İLO ALINMASI}

\section{İ.A.Talıblı, Q.M.Səmədzadə, F.M.Sadıxov, A.M.Qasımova, V.A.Qasımov, G.V.Şadlinskaya}

Koaksial kənarları olan boşqabvari ikişöbəli dənəvərləşdiricidə eyni diametrli bağlayıcı maye damcısının təsirilə gil tozundan verilmiş ölçüdə dənəvər alınması tədqiq edilmişdir. Birinci şöbədə toz artıqlığı ilə, ikinci şöbədə isə tozsuz dənəvərləşdirmənin optimal müddəti müəyyən edilərək, sferikliyi 0.85-dən az olmayan, eyni dənəvərləşdirici tərkibə malik dairəvi dənəvər alınmışdır. Müəyyən edilmişdir ki, əmələ gələn dənəvərlərin ölçüsü bağlayıcı maye damcısının ölçüsü ilə müəyyən edilir, davamlılığı isə onların diametrinin artması ilə yüksəlir. Lakin diametrin artması ilə davamlılıq həddi azalır. Göstərilmişdir ki, dənəvərlərin potensial mexaniki davamlılığına daha çox dənəvərləşdirmə prosesinin ilkin mərhələləri təsir edir. Verilmiş ölçüdə dənəvərlərin alınması üçün məhlul damcılarının ölçüsünün dənəvərlərin diametrindən asılılı̆̆ı müəyyən edilmişdir.

Açar sözlar: ikişöbəli danəvarlaşdirici, tozvari gil, bağlayıcı maye damcısıları, davamlılıq haddi, dənəvarlaşdirma vaxtı.

\section{КАПЕЛЬНЫЙ МЕТОД ПОЛУЧЕНИЯ ГРАНУЛ ОДИНАКОВОГО ДИАМЕТРА ИЗ ПЫЛЕВИДНОЙ ГЛИНЫ НА ТАРЕЛЬЧАТОМ ГРАНУЛЯТОРЕ}

\section{И.А.Талыблы, Г.М.Самедзаде, Ф.М.Садыхов, А.М.Гасымова, В.А.Гасымов, Г.В.Шадлинская}

В тарельчатом двухсекционном грануляторе с коаксиальными бортиками исследовано получение гранул заданного размера из порошка глины воздействием капель связующей жидкости одинакового диаметра. Установлены оптимальное время грануляции в первой секции с избытком порошка и во второй секции без порошка, способствующие получению округлых гранул со сферичностью не менее 0.85 и одинаковым гранулометрическим составом. Установлено, что величина формирующихся гранул определяется размером подаваемых капель связующей жидкости, а прочность возрастает с увеличением их диаметра. Однако с увеличением диаметра предел прочности уменьшается. Показано, что на потенциальную механическую прочность гранул в наибольшей степени оказывают влияние начальные стадии процесса грануляции. Для получения гранул заданного размера определена зависимость величины капель раствора от диаметра гранул.

Ключевые слова: двухсекционный гранулятор, порошкообразная глина, капли связующей жидкости, предел прочности, время грануляции. 